Artikkel:

\title{
Dualismen i norsk rett som konstitusjonell norm
}

av Sondre Torp Helmersen

s.t.helmersen@jus.uio.no

Stipendiat, Institutt for offentlig rett, Det juridiske fakultet, Universitetet i Oslo

[Takk til Sofie A. E. Høgestøl, Stian Øby Johansen, Anders Narvestad, Geir Ulfstein, Kritisk

Juss-redaksjonen, og anonyme fagfeller for nyttige debatter og viktige innspiller til teksten.]

\section{Sammendrag:}

Den rådende oppfatningen i norsk rett er at folkerett må gjennomføres for å bli en bindende del av norsk rett (gjerne kalt “dualisme”). Noe som er mindre klart er hvorvidt denne normen har konstitusjonell rang. Dette hevdes av enkelte kilder. Denne artikkelen tar opp mulige argumenter for hvorfor dette kan eller må være tilfelle.

\section{Innhold:}

1. Innledning

2. Rettskildelæren som konstitusjonelle normer

2.1 Argumentet

2.2 Rettskildelæren følger ikke av Grunnloven

2.3 Rettskildelæren (og dualismen) kan være konstitusjonell sedvanerett

3. Dualismen følger ikke av Grunnloven

3.1 Innledning: to formål

3.2 Grunnlovens maktfordeling er kun et reelt hensyn

3.3 Grunnloven § 26 forutsetter ikke konstitusjonell norm

3.4 Legalitetsprinsippet har ikke betydning

4. Forrang foran lov krever trinnhøyere norm

5. Rettspraksis er taus om dualismens rang

5.1 Innledning

5.2 Rettspraksis om folkerettens stilling i norsk rett

5.3 Betydning for dualismens rang

6. Konklusjon 


\section{Innledning}

Folkerettens stilling i nasjonal rett reguleres av regler i det enkelte nasjonale rettssystemet. ${ }^{1}$ I norsk rett må folkeretten gjennomføres for å bli del av norsk rett. Dette beskrives gjerne som "dualistisk", som motsetning til "monistisk”. Begrepene "dualisme” og "monisme” har ulike og til dels uklare betydninger. I denne artikkelen brukes begrepene slik: "Dualisme” angir en norm i norsk rett som sier at folkerettslige regler må gjennomføres ved hjelp av transformasjon og/eller inkorporering for å bli en av norsk rett, mens "monisme” angir en potensiell generell norm som ville gjort folkerettslige bestemmelser uten videre direkte anvendelige i norsk rett. Denne begrepsbruken er kun ment å gjøre teksten enklere, intensjonen er ikke å ta noen stilling til den bredere debatten over begrepenes definisjon.

Spørsmålet artikkelen forsøker å besvare, er hvorvidt normen som sier at norsk rett er dualistisk har konstitusjonell rang. Spørsmålet er ikke direkte regulert i Grunnloven. Noen hevder at det framkommer indirekte, andre mener dualismen er en del av vår konstitusjonelle sedvanerett. Men har dette noen praktisk betydning? Først og fremst vil det påvirke Stortingets adgang til å vedta lovgivning som berører folkerettens stilling i norsk rett. Hvis dualismen ikke har grunnlovs rang kan man jo tenke seg at Stortinget kan endre på det og dermed vedta generell monisme gjennom vanlig lov. Hvis dualismenormen derimot er konstitusjonell, vil det sette grenser for hvor langt Stortinget kan gå i å gjøre folkerett til norsk rett gjennom vanlig lov. Dette utdypes i punkt 2.3 nedenfor. Spørsmålet om dualismenormens rang har også betydning for hvordan Høyesterett og andre rettsanvendere må gå frem for å finne dualismens nærmere innhold. Hvis dualismen følger av Grunnloven, må man benytte grunnlovstolkning. Følger den derimot av (konstitusjonell) sedvanerett, er det metoden for å fastlegge slik sedvanerett som må brukes. Potensielle og tidligere fremsatte argumenter for dualismens konstitusjonelle rang diskuteres i punkt 2-5 nedenfor.

Flertallet av kildene som diskuterer dualismen, nevner ikke spørsmålet om rang overhodet. De kildene som mener at dualismen er konstitusjonell, fremsetter få (om noen) argumenter for dette, og diskuterer spørsmålet i beste fall overfladisk.

Noen forfattere hevder at dualismen er konstitusjonell. Johs Andenæs skriver at skriver at det å gi folkerett rang foran lov er «vanskelig å forene med vårt forfatningssystem», ${ }^{2}$ noe som tilsynelatende betyr at dualismen har konstitusjonell rang. Halvard Haukeland Fredriksen skriver at «vår konstitusjon bygger på det dualistiske prinsipp». ${ }^{3}$ Carsten Smith skriver at dualismen i

\footnotetext{
${ }^{1}$ Se for eksempel Eileen Denza, «The Relationship Between International and National Law», i Malcolm Evans (red.), International Law, 4. utg. Oxford 2014, s. 412-440, s. 418-425 for eksempler på ulike løsninger i nasjonale rettssystemer.

${ }^{2}$ Johs Andenæs, Statsforfatningen i Norge, 8. utg. Oslo 1998 s. 5.

${ }^{3}$ Halvard Haukeland Fredriksen, «Bokanmeldelse: Finn Arnesen og Are Stenvik: Internasjonalisering og juridisk metode. Universitetsforlaget, Oslo 2009. 160 sider», Lov og Rett, 2010 s. 98-101, s. 101.
} 
norsk rett er «assumed to be customary rules of constitutional law». ${ }^{4}$ Eivind Smith skriver, blant annet, at dualismen «følger av Grunnloven selv». ${ }^{5}$ Komitéen bak NOU 1993:18 «mente grunnlovsendring ville være påkrevd hvis det monistiske system skulle innføres i Norge», ${ }^{6}$ som nødvendigvis innebærer at den eksisterende dualismen har konstitusjonell rang.

Andre lovforarbeider som omtaler norsk rett som dualistisk, sier ikke noe om at normen har konstitusjonell rang. ${ }^{7}$ Flere av forarbeidene begrunner ikke sitt standpunkt med (ytterligere) rettskilder. ${ }^{8}$ Noen viser derimot til rettspraksis, ${ }^{9}$ noen til andre forarbeider, ${ }^{10}$ og noen til juridisk teori ${ }^{11}$. Dessuten har det ved to anledninger i NOUer blitt fremmet forslag om grunnlovsfesting av monisme (NOU 1972:16 og NOU 1993:18). Begge forslagene ble forkastet. ${ }^{12}$ Forslagene bygget på en antagelse om at norsk rett var dualistisk. ${ }^{13}$

Det meste av nyere juridisk litteratur legger til grunn at norsk rett er dualistisk, men uten å si noe om at normen har konstitusjonell rang. ${ }^{14}$ Tekstene begrunner som regel dualismens eksistens med henvisninger til rettspraksis, ${ }^{15}$ forarbeider, ${ }^{16}$ annen juridisk litteratur, ${ }^{17}$ og at det følger implisitt av inkorporasjonsregler ${ }^{18}$ og Grunnloven $\S 26^{19}$.

\footnotetext{
${ }^{4}$ Carsten Smith, «International Law In Norwegian Courts», Scandinavian Studies in Law, 1968 s. 151-201, s. 156.

${ }^{5}$ Eivind Smith, «Vil de som er imot, rekke opp hånden? - Om menneskerettigheter, (annen) rett og demokrati», Nytt Norsk Tidsskrift, 2011 nr. 1 s. 49-59, fotnote 10; se også Eivind Smith, Konstitusjonelt demokrati:

Statsforfatningsretten i prinsipielt og komparativt lys, 2. utg. Bergen 2012 s. 157-159.

${ }^{6}$ NOU 1993:18 s. 76.

${ }^{7}$ Dette gjelder blant annet NOU 1993:18 s. 75, NOU 2002:12 s. 108, Ot.prp. nr. 3 (1998-9) s. 12, Ot.prp. nr. 33 (2004-5) s. 53, Ot.prp. nr. 93 (2008-9) s. 11, Ot.prp. nr. 35 (2004-5) s. 69, Dok. 16 (2011-2012) s. 31, Ot.prp. nr. 79 (1991-2) s. 3, Innst. O. nr. 51 (1998-9) kap. 3, Innst. 69 S (2013-2014) s. 3, Ot.prp. nr. 45 (2002-3) s. 13, og St.meld. nr. 17 (2004-5) s. 63.

${ }^{8}$ Ot.prp. nr. 45 (2002-3) s. 13, Innst. 69 S (2013-2014) s. 3, Ot.prp. nr. 79 (1991-2) s. 3, Dok. nr. 16 (2011-2) s. 31, Ot.prp. nr. 35 (2004-5) s. 69, Ot.prp. nr. 33 (2004-5) s. 5. Utenriksdepartementet, Folkerettslige avtaler: Om forhandling og inngåelse av folkerettslige avtaler, Oslo 2013 s. 15 og 68 gjør det samme.

${ }^{9}$ Ot.prp. nr. 3 (1998-9) s. 12-13, Innst. O. nr. 51 (1998-9) kap. 3.

${ }^{10}$ Ot.prp. nr. 93 (2008-9) s. 11, St. Meld. nr. 17 (2004-5) s. 63.

11 NOU 2002:12 s. 108-111.

12 Ot. prp. 3 1998-9 s. 12 har en oversikt over prosessen.

${ }^{13}$ Erik Boe, Innføring i juss: Juridisk tenkning og rettskildelære, 3. utg. Oslo 2010 s. 110, Carl August Fleischer, Rettskilder og juridisk metode, Oslo 1998 s. 515-516; Carl August Fleischer, Folkerett, 8. utg. 2005 s. 359-360.

${ }^{14}$ Se imidlertid Torstein Eckhoff og Jan Erik Helgesen, Rettskildelcre, 5. utg. Oslo 2001 s. 317-325 for et mer nyansert syn.

${ }^{15}$ Carl August Fleischer, Folkerett, 8. utg. Oslo 2005 s. 359, Johs Andenæs og Arne Fliflet, Statsforfatningen $i$ Norge, 10. utg. Oslo 2006 s. 30, Erik Boe, Innføring i juss: Juridisk tenkning og rettskildelære, 3. utg. Oslo 2010 s. 110, Nils Nygaard, Rettsgrunnlag og standpunkt, 2. utg. Bergen 2004 s. 53, Morten Ruud og Geir Ulfstein, Innføring i folkerett, 4. utg. Oslo 2011 s. 56-58, Mads Henry Andenæs, Rettskildelære, 2. utg. Oslo 2009 s 58, Finn Arnesen og Are Stenvik, Internasjonalisering og juridisk metode: Scrlig om EØS-rettens betydning i norsk rett, Oslo 2009 s. 49, Inge Lorange Backer, «Lovgivere og domstoler ved begynnelsen av det 21. århundre», Jussens Venner, 2006 s. 248-266, s. 251, Hans Petter Graver, «Internasjonale konvensjoner som rettskilde», Lov og Rett, 2003 s. 468-489, s. 474-475, Erik Boe, Rettskildelcere under debatt, Oslo 2012 s. 388, Fredrik Sejersted mfl., EØSrett, 3. utg. Oslo 2011 s. 272-273.
} 
I sammenheng med dualismen er også presumsjonsprinsippet relevant. ${ }^{20}$ På grunn av dette, kan man si at folkeretten er en "relevant rettskilde” i norsk rett selv uten å være gjennomført. Det som i denne artikkelen kalles “dualisme” kan derfor sies å i praksis være uthulet, ettersom det strengt tatt bare kommer på spissen i tilfeller hvor anvendelse av presumsjonsprinsippet ikke kan føre til harmoni mellom norsk rett og folkeretten. Dette skjer først og fremst når en regel i norsk rett er uttrykkelig ment å være i strid med en ikke-gjennomført folkerettsregel som Norge er bundet av. Det kan også skje når folkeretten ikke har blitt godt nok utredet før vedtagelsen av norske regelen, eller når folkeretten har endret seg siden vedtakelsen av den norske regelen. Denne artikkelen omhandler den normen i norsk rett som regulerer disse situasjonene.

Det er dessuten mulig at dualismen ikke er en norm, men snarere fraværet av en norm som sier noe generelt om folkerettens stilling i norsk rett. Eivind Smith skriver at «[h]vis konstitusjonen åpner for at folkeretten under visse forutsetninger får direkte virkning i nasjonal rett uten at nasjonale myndigheter har truffet særskilt vedtak om dette, taler vi om monisme», ${ }^{21}$ noe som kanskje kan tas til inntekt for et slikt standpunkt. Slik dualismen omtales i rettspraksis og juridisk

\footnotetext{
${ }^{16}$ Finn Arnesen og Are Stenvik, Internasjonalisering og juridisk metode: Scrlig om EØS-rettens betydning i norsk rett, Oslo 2009 s. 49, Inge Lorange Backer, «Lovgivere og domstoler ved begynnelsen av det 21. århundre», Jussens Venner, 2006 s. 248-266, s. 251, Jon Petter Rui Johansen, «Ikke inkorporert folkerett i konflikt med norsk rett», i Per Christiansen (red.), Jubileumsskrift til Universitetet i Tromsø: Fra Driftssentralen til Teorifagbygget, Tromsø 2004 s. 117-131, s 117, Marius Emberland, «To måter å bringe rettigheter hjem på», Retfcerd, 2002 s. 3-22, fotnote 10, Kai Krüger, «Finanger-dommen og den nye rettskildefaktor: frykten», Jussens Venner, 2001 s. 89-104, s. 91, Jens Edvin Andreassen Skoghøy, «Forholdet mellom internasjonale menneskerettigheter og norsk rett», Kritisk Juss, 1998 s. 111-119, s. 111, Jens Edvin Andreassen Skoghøy, «Norske domstolers lovkontroll i forhold til inkorporerte menneskerettskonvensjoner», Lov og Rett, 2002 s. 337-354, s. 338, Jens Edvin Andreassen Skoghøy, «Høyesteretts bruk av menneskerettskonvensjonene som rettskilde før og etter menneskerettsloven», i Peter Lødrup mfl. (red.), Rettsteori og rettsliv: festskrift til Carsten Smith, Oslo 2002 s. 733-761, s. 733, Kai Krüger, «Kampen om begrepene - En feltrapport fra EØS-fronten: Stat, politikk og folkestyre», i David Doublet mfl. (red.), Festskrift til Per Stavang på 70-årsdagen 19. Februar, Bergen 1998 s. 429-454, s. 429, Kai Krüger, «Svensk privatrett sett fra norsk side samt noen refleksjoner over nordisk rettsidentitet i privatrettsforskningen med blikk mot fortid og fremtid», i Stig Strömholm (red.), Svensk rättsvetenskap 1947-1997, Stockholm 1997 s. 23-59, s. 35, Helga Aune, «Likebehandlingsprinsippet og arbeidstakere i deltidsstilling», Institutt for offentlig retts skriftserie,1997 nr. 2 s. 1116, s. 29, Jørgen Aall, «Menneskerettighetskonvensjoner som rettskildefaktor i intern norsk rett», Tidsskrift for rettsvitenskap, 1989 s. 613-639, s. 616.

${ }^{17}$ Morten Ruud og Geir Ulfstein, Innføring i folkerett, 4. utg. Oslo 2011 s. 56, Finn Arnesen og Are Stenvik, Internasjonalisering og juridisk metode: Scerlig om EØS-rettens betydning i norsk rett, Oslo 2009 s. 49, Helga Aune, «Likebehandlingsprinsippet og arbeidstakere i deltidsstilling», Institutt for offentlig retts skriftserie, $1997 \mathrm{nr}$. 2, s. 1-116, s. 29, Henrik Bull, «The EEA Agreement and Norwegian Law», European Business Law Review, 1994 nr 12 s. 291-296, s. 292, Erik Boe, Rettskildelære under debatt, Oslo 2012 s. 388.

${ }^{18}$ Erik Boe, Innføring i juss: Juridisk tenkning og rettskildelcere, 3. utg. Oslo 2010 s. 110.

${ }^{19}$ Carl August Fleischer, Folkerett, 8. utg. Oslo 2005 s. 370, Mads Henry Andenæs, Rettskildelære, 2. utg. Oslo 2009 s. 58, Gro Nystuen «Rasediskriminerende ytringer og organisasjoner», Institutt for offentlig retts skriftserie, 1991 nr. 4 s. $1-127$, s. 18.

${ }^{20}$ Jf. for eksempel Rt. 2000 s.1811 på s. 1826, og Torstein Eckhoff og Jan Erik Helgesen, Rettskildelcre, 5. utg. Oslo 2001 s. 316.

${ }^{21}$ Eivind Smith, Konstitusjonelt demokrati: Statsforfatningsretten i prinsipielt og komparativt lys, 2. utg. Bergen 2012. s. 157-158.
} 
teori, er imidlertid ikke dette noe nærliggende alternativ. Dualismen defineres ofte som en norm om at norsk rett «går foran» folkeretten ved motstrid e.l., og dette begrunnes med henvising til kilder, og ikke til fravær av kilder. At dualismen har konstitusjonell rang (som hevdes av, blant andre, nettopp Eivind Smith) er heller ikke forenelig med at dualismen kun er et fravær av normer: Det gir ikke mening å si at et slikt fravær har konstitusjonell rang.

For å klargjøre hvorvidt dualismen har konstitusjonell rang, diskuterer jeg ulike mulige argumenter for dette standpunktet. Punkt 2 nedenfor gjelder et argument om at rettskildelæren generelt (og dermed dualismen) må være konstitusjonell. Punkt 3 omhandler tre argumenter som er basert Grunnlovens system og tekst. Punkt 4 gjelder et argument om hvilken rang en eventuell monismenorm må vedtas. I punkt 5 diskuterer jeg betydningen av rettspraksis, som foreløpig ikke har tatt stilling til hvilken rang dualismenormen har. Punkt 6 er en konklusjon.

\section{Rettskildelæren som konstitusjonelle normer}

\subsection{Argumentet}

Hvis rettskildelæren i et rettssystem nødvendigvis må ha konstitusjonell rang, vil også dualismen måtte ha slik rang. At rettskildelæren generelt er konstitusjonell, hevdes tilsynelatende av Eivind Smith. Han skriver generelt at «[d]et er konstitusjonen som avgjør hvilken status en rettsregel kan eller skal ha i den nasjonale rett» og at man må «gå til konstitusjonen for å beskjed om hvilke rettsregler som gjelder i en stat». ${ }^{22}$ For dualismen spesielt betyr dette at «[h]vis konstitusjonen åpner for at folkeretten under visse forutsetninger får direkte virkning i nasjonal rett uten at nasjonale myndigheter har truffet særskilt vedtak om dette, taler vi om monisme». ${ }^{23}$

Smiths konstitusjonsbegrep omfatter både Grunnloven og eventuell konstitusjonell sedvanerett (dersom denne eksisterer). ${ }^{24}$ Jeg diskuterer hvorvidt rettskildelæren følger av Grunnloven i punkt 2.2, og hvorvidt den følger av konstitusjonell sedvanerett i punkt 2.3. Smith mener imidlertid at dualismen «følger av Grunnloven selv». ${ }^{25}$ Dette diskuterer jeg i punkt 3 nedenfor.

\subsection{Rettskildelæren følger ikke av Grunnloven}

Den norske Grunnloven regulerer ikke norsk rettskildelære generelt. Dette er ikke i seg selv problematisk. Det er ikke slik at rettskildelæren i et rettssystem behøver å følge av grunnloven.

\footnotetext{
${ }^{22}$ Eivind Smith, Konstitusjonelt demokrati: Statsforfatningsretten i prinsipielt og komparativt lys, 2. utg. Bergen 2012 s. 157-158.

${ }^{23}$ Eivind Smith, Konstitusjonelt demokrati: Statsforfatningsretten i prinsipielt og komparativt lys, 2. utg. Bergen 2012, s. $157-158$

${ }^{24}$ Eivind Smith, Konstitusjonelt demokrati: Statsforfatningsretten i prinsipielt og komparativt lys, 2. utg. Bergen 2012 s. 63-64 og 70).

${ }^{25}$ Eivind Smith, «Vil de som er imot, rekke opp hånden? - Om menneskerettigheter, (annen) rett og demokrati», Nytt Norsk Tidsskrift, 2011 nr. 1 s. 49-59, fotnote 10.
} 
Den norske rettskilden sedvanerett illustrerer dette. Sedvaneretten er ikke nevnt i Grunnloven, og dens status som rettskilde kan ikke utledes fra noen av Grunnlovens bestemmelser. ${ }^{26}$ Det er likevel klart at dette er en rettskilde i norsk rett, slik som også lovgivning, rettspraksis, og Grunnloven selv er.

Mer generelt kan man si at rettskildelæren i en stat i siste instans nødvendigvis må ha et ulovfestet grunnlag. Selv om en grunnlov pretenderer å regulere rettskildelæren, må grunnlaget for grunnlovens egen stilling som rettskilde være ulovfestet. Selve rettskildelæren må dessuten ha et grunnlag utenfor retten selv, i form av en sosial konsensus og/eller moralsk forpliktelse. Det er kun hvis dette grunnlaget - de aktuelle sosiale fakta eller moralske forpliktelser - sier at grunnloven er kilden til all rettskildelære, at dette faktisk vil være tilfellet. Det er ingenting i veien for at det sosiale eller moralske grunnlaget for retten kan si noe annet.

Dette mer generelle poenget kan illustreres av at skrevne reguleringer av rettskildelære i praksis sjelden er uttømmende. ICJ-statuttene artikkel 38 har en liste med folkerettslige rettskilder (trakter, sedvanerett, prinsipper, rettspraksis, juridisk litteratur), men det er enighet om disse må suppleres med iallfall ensidige erklæringer og vedtak fra mellomstatlige organisasjoner. ${ }^{27}$ Artikkel VI i USAs grunnlov regulerer rettskildelæren i USAs føderale rett, men denne er heller ikke uttømmende; den nevner ikke common law. Disse eksemplene viser altså at selv ikke en uttrykkelig grunnlovsfesting av rettskildelæren behøver å være uttømmende. Den eneste måten man kan være sikker på at en slik regulering er uttømmende, er hvis den uttrykkelig sier dette. Kort sagt, det å kreve og lete etter grunnlovshjemmel for enhver regulering av rettskildelæren (herunder folkerettens stilling) vil som regel være fåfengt, selv i rettssystemer der grunnloven (i motsetning til den norske) uttrykkelig regulerer rettskildelæren.

\subsection{Rettskildelæren (og dualismen) kan være konstitusjonell sedvanerett}

At dualismen har konstitusjonell rang, må innebære at den følger av Grunnloven eller av konstitusjonell sedvanerett. At dualismen ikke behøver å følge av Grunnloven, ble vist i forrige punkt. Dette punktet handler om konstitusjonell sedvanerett.

Dualismen i norsk rett kan følge av ulovfestet rett. Det er vanlig å kalle slik rett sedvanerett, og si at den skapes ved langvarig fast praksis basert på rettsoppfatning. I praksis er imidlertid fastleggelsen av ulovfestet rett først og fremst styrt av domstolene. ${ }^{28}$ Sedvanerett kan ha ulik

\footnotetext{
${ }^{26}$ Johs Andenæs og Arne Fliflet, Statsforfatningen i Norge, 10. utg. Oslo 2006 s. 45.

27 Jf. for eksempel Hugh Thirlway, «The Sources of International Law», i Malcolm Evans (red.), International Law, 4. utg. 2014 s. 91-117, s. 111-114. Disse elementene kan også komme inn som tolkningsmomenter når man tolker traktater (jf. Wien-konvensjonen om traktatretten Artikkel 31-32), men her omtaler jeg dem som selvstendige rettskilder, og ikke bare som momenter i traktattolkning.

${ }^{28}$ Jf. for eksempel Torstein Eckhoff og Jan Erik Helgesen, Rettskildelcere, 5. utg. Oslo 2001 s. 265-268.
} 
rang, herunder konstitusjonell rang og samme rang som lovgivning. Sedvanerett med konstitusjonell rang kalles gjerne konstitusjonell sedvanerett. Dualisme er imidlertid ikke nevnt som eksempel på konstitusjonell sedvanerett av juridisk litteratur som omtaler temaet generelt. ${ }^{29}$ At dualismen er konstitusjonell sedvanerett, hevdes tilsynelatende av NOU 1993:18, som begrunnet dette med at det foreligger «lang konstitusjonell praksis for det dualistiske system». ${ }^{30}$

Slik "konstitusjonell praksis" er praksis fulgt av statsorganene (regjering, Stortinget, Høyesterett), angående forholdet mellom dem, tilknyttet reglene i Grunnloven. ${ }^{31}$ Man kan si at Stortinget ved sin lovgivningspraksis har forutsatt at norsk rett er dualistisk. Stortinget har vedtatt bestemmelser om sektormonisme, ${ }^{32}$ som innebærer at en lov "gjelder med de begrensninger som er anerkjent i folkeretten eller følger av overenskomst med fremmed stat”. 33 Det har også vedtatt lovbestemmelser som inkorporer ${ }^{34}$ bestemte folkerettsregler i norsk rett, slik som menneskerettsloven $\S 2$ og EØS-loven) $\S 1$. Dessuten gir EØS-konkurranseloven $\S 4$ bøter utstedt av ESA i konkurransesaker direkte virkning i norsk rett. ${ }^{35}$ Disse lovbestemmelsene ville vært meningsløse dersom folkeretten allerede var del av norsk rett før de ble vedtatt. Man kan også si at regjeringen og Høyesterett ved sin praksis har til grunn at norsk er dualistisk, herunder ved å forholde seg til de ovennevnte lovbestemmelsene. ${ }^{36}$ Dessuten kan det hevdes at folkerettens stilling i norsk rett har - eller iallfall kan ha - betydning for forholdet mellom Storting, regjering og domstoler. Dette kan man imidlertid si om alle rettskildenormer i norsk rett. Den rettskildemessige stillingen til lovgivning, kongelige resolusjoner, rettspraksis og så videre utgjør mye av grunnlaget for statsorganenes myndighet og forholdet mellom dem. Logisk sett står derfor valget mellom å anse enten all eller ingen rettskildelære som konstitusjonell; det er ingen synlig grunn til å skille ut dualismen og folkeretten særskilt. På grunnlag av dette ser det imidlertid ut til å at både dualismen og rettskildelæren er konstitusjonell.

\footnotetext{
${ }^{29}$ Johs Andenæs og Arne Fliflet, Statsforfatningen i Norge, 10. utg. Oslo 2008 s. 40, Per Helset og Bjørn Stordrange, Norsk statsforfatningsrett, Oslo 1998 s. 79-86, Jan Erik Helgesen, «Om den såkalte "konstitusjonelle sedvanerett”», Jussens Venner, 1977 s. 193-240, Fredrik Sejersted, Kontroll og konstitusjon, Oslo 2002 s. 75-78. Eivind Smith, Konstitusjonelt demokrati: Statsforfatningsretten i prinsipielt og komparativt lys, 2. utg. Bergen 2012 s. 142 nevner «det dualistiske forholdet mellom norsk rett og folkeretten» som en av «[d]e påståtte [konstitusjonelle] sedvanerettsreglene», men mener at den heller bør ses som del ”av Grunnloven selv” (jf. Eivind Smith, «Vil de som er imot, rekke opp hånden? - Om menneskerettigheter, (annen) rett og demokrati», Nytt Norsk Tidsskrift, 2011 nr. 1 s. 49-59, fotnote 10).

${ }^{30}$ NOU 1993:18 s. 76.

${ }^{31}$ Jf. for eksempel Arne Fliflet, Grunnloven: Kommentarutgave, Oslo 2005 s. 19.

32 Jan Helgesen, Teorier om "Folkerettens stilling i norsk rett”, Oslo 1982 s. 53.

${ }^{33}$ Tvisteloven §1-2. Jf. for eksempel også tvangsl. § 1-4, strpl. § 4, strl. § 1, strl. 2005 §, 2 og politil § 3. En lignende definisjon finnes i Geir Ulfstein, ”Internasjonal miljøretts stilling i norsk rett”, Lov og Rett, 1999 s. 402-417, s. 406, som sier at sektormonisme betyr at "folkeretten er gjort til norsk rett gjennom at lovgivningen henviser til folkeretten på et bestemt saksområde".

${ }^{34}$ Det er mulig å kalle sektormonisme en form for "inkorporasjon” av folkerett i norsk rett (jf. begrepsbruk i for eksempel Geir Ulfstein, ”Internasjonal miljøretts stilling i norsk rett”, Lov og Rett, 1999 s. 402-417, s. 406, og Lars Oftedal Broch, ”Den Europeiske menneskerettighetskonvensjonens inkorporering i norsk rett”, Mennesker og rettigheter, 2000, s. 176-181, s. 176). Det er imidlertid mulig å trekke et analytisk skille mellom sektormonisme, som gjør et ubestemt antall folkerettsregler relevante i en bestemt del av norsk rett, og inkorporasjon, som gjør bestemte folkerettsregler relevante for all norsk rett.

${ }^{35}$ Stian Øby Johansen, «Den internasjonale rettens påvirkning på norsk rett», Pacta, nr 232014 s. 34-37, s. 36.

36 Johs Andenæs, Statsforfatningen i Norge, 8. utg. Oslo 1998 s. 5.
} 
Hvis dualismenormen er konstitusjonell, vil regler med lavere rang som strider mot dualismen være ugyldige, etter lex superior-prinsippet. I denne forbindelse kunne man seg tenke seg at enhver regel som bringer folkerett inn i norsk rett, ville være ugyldig. Dette kunne blant annet ramme bestemmelser om sektormonisme og (annen) inkorporasjon nevnt ovenfor, og EØSkonkurranseloven $\S 4$. Videre, dersom hele den generelle rettskildelæren også skal anses som konstitusjonell, ville blant annet ramme menneskerettighetsloven $\S 3$ og EØS-loven § 2, som gir visse inkorporerte folkerettsregler "forrang” foran øvrige regler, rammes på samme måte. ${ }^{37}$

Det synes imidlertid som om alle disse lovbestemmelsene er gyldige. De har blitt omtalt og anvendt utallige ganger i rettspraksis, forarbeider og juridisk litteratur, uten noen at noen i det hele tatt har sett grunn til å stille spørsmål ved deres grunnlovsmessighet. Dersom dualismenormen er konstitusjonell, med den derfor etter sitt innhold åpne for at folkerett gjennomføres i norsk rett ved lov. Dersom en konstitusjonell regel selv åpner for slike ”fravikelser” i lovs form, vil ikke ”fravikelsene” rammes av lex superior-prinsippet.

Den praktiske konsekvensen av at en sedvanerettsregel er konstitusjonell, er normalt at den ikke kan fravikes ved lov eller andre regler med tilsvarende eller lavere rang. Dersom rettskildelæren er konstitusjonell, ville man altså ha normer som ikke kan fravikes ved lov (siden de er konstitusjonelle), men som selv sier uttrykkelig at de kan fravikes ved (visse) lovvedtak. Dette virker selvmotsigende, men det er mulig.

Et spørsmål blir da hvor langt den konstitusjonelle sedvaneretten om rettskildelæren og dualismen kan fravikes ved lov. Hvis Stortinget generelt står helt fritt til å vedta enhver rettskildenorm i lovs form, blir det i praksis meningsløst å kalle rettskildelæren konstitusjonell. Dette gjelder ikke bare rettskildelæren generelt, men også for dualismen spesielt. Stortinget har tydeligvis adgang til å vedta sektormonisme og inkorporasjon av folkerett, men hvis Stortinget står fritt til å vedta helt generell monisme i vanlig lovs form, blir dualismens konstitusjonelle stilling fullstendig uthulet og meningsløs. Spørsmålet blir da nøyaktig hvor langt Stortinget kan gå i vedta i lovs form at folkerett skal være del av norsk rett. Dette har ikke blitt testet i praksis.

I lys av at sektormonisme- og inkorporasjonsbestemmelser har blitt (tilsynelatende) gyldig vedtatt, kunne man kanskje tro at grensen går ved lovbestemmelser som gjør noe mer enn å gjennomføre bestemte traktater i norsk rett eller å la bestemte lovregler vike for folkeretten. Dette ville være en dualismenorm med positivt angitte unntak, i den forstand at Stortinget bare kan bruke nærmere angitte lovgivningsformer for å gjennomføre folkerett i norsk rett. I denne forbindelse fremstår EØS-konkurranseloven § 4 som noe overraskende, siden den gjør noe ganske annet, nemlig å gi vedtak fra en internasjonal organisasjon direkte virkning i norsk rett. Man kan eventuelt legge til dette som enda en tillatt kategori ved siden av sektormonisme og inkorporasjon. En annen, mer plausibel, synsvinkel, er at dualismenormens unntak ikke er positivt angitt, men derimot negativt avgrenset: Stortinget kan vedta lovbestemmelser som gjør folkerett til norsk rett, så lenge Stortinget ikke vedtar noe som gjør et ubestemt sett av folkerettsregler (sml. inkorporasjon) relevante i norsk rett generelt (sml. sektormonisme).

37 Jf. for eksempel Fredrik Sejersted mfl., EØS-rett, 2. utg. Oslo 2011 s. 245. 
Å trekke denne grensen vil imidlertid i praksis være overlatt til domstolene (jf. punkt 5 nedenfor).

\section{Dualismen følger ikke av Grunnloven}

\subsection{Innledning: to formål}

I dette punktet tar jeg opp argumenter, basert på Grunnlovens tekst, som har blitt fremsatt av andre, for hvorfor dualismen er konstitusjonell. Dette har to formål: Det første er å vurdere hvorvidt disse argumentene tilsier at dualismen følger av Grunnloven. Det andre er å vurdere hvorvidt de samme argumentene tilsier at en sedvanerettslig dualismenorm må ha konstitusjonell rang

Eivind Smith skriver at dualismen "følger av Grunnloven selv”. ${ }^{38}$ Det finnes imidlertid ingen uttrykkelig skriftlig regulering av spørsmålet i Grunnlovens tekst. ${ }^{39}$ Som vist i kapittel 2, behøver alle rettskilder i et rettssystem å være uttrykkelig nevnt i rettssystemets grunnlov. Det at Grunnloven ikke omtaler folkerett som en rettskilde, er altså ikke til hinder for at norsk rett kan ha noe annet enn absolutt dualisme.

Eivind Smith ser ut til å anta at dualismen følger av Grunnlovens system. Dette argumentet diskuteres i punkt 3.2. Grunnloven $\S 26$ annet ledd diskuteres i punkt 3.3. Legalitetsprinsippet i Grunnloven $\S 113$ diskuteres i punkt 3.4. Konklusjonen i samtlige kapitler er at disse argumentene ikke viser at dualismen følger av Grunnloven, at de heller ikke sier noe om rangen til en sedvanerettslig dualismenorm.

\subsection{Grunnlovens maktfordeling er kun et reelt hensyn}

Eivind Smith skriver at Grunnlovens regler om myndighetsfordeling mellom statsorganene «er uttømmende i den forstand at overføring av tilsvarende beslutningsmyndighet til andre vil representere avvik og dermed kreve grunnlovsendring». ${ }^{40}$ Han skriver også at «[b]are de organer som grunnloven konstituerer (den lovgivende makt osv.), kan gjøre folkerettsregler til norsk rett» ${ }^{41}$ og at «de vanlige reglene om beslutningsmyndighet i nasjonal rett [må] benyttes for å

\footnotetext{
${ }^{38}$ Eivind Smith, «Vil de som er imot, rekke opp hånden? - Om menneskerettigheter, (annen) rett og demokrati», Nytt Norsk Tidsskrift, 2011 nr. 1 s. 49-59, fotnote 10.

${ }^{39}$ Carsten Smith, «Folkerettens stilling ved norske domstoler», Tidsskrift for rettsvitenskap, 1964 s. 356-374, s. 357.

${ }^{40}$ Eivind Smith, Konstitusjonelt demokrati: Statsforfatningsretten i prinsipielt og komparativt lys, 2. utg. Bergen 2012 s. 158.

${ }^{41}$ Eivind Smith, Konstitusjonelt demokrati: Statsforfatningsretten i prinsipielt og komparativt lys, 2. utg. Bergen 2012 s. 159.
} 
fastsette hvilke [folkerettslige] regler som skal gjelde [som norsk rett]». ${ }^{42}$ Carl August Fleischer fremsetter et lignende argument, men, i motsetning til Smith, uten å knytte det til at dualismen må være en konstitusjonell norm. ${ }^{43}$ Johs Andenæs skriver at det å gi folkerett rang foran lov er «vanskelig å forene med vårt forfatningssystem». ${ }^{44}$

Grunnloven fordeler makt mellom statsorganene. Stortinget kan gi lover (Grunnloven § 49 og 75 bokstav a). Regjeringen kan inngå traktater (§ 26), men ofte kun med Stortingets medvirkning (§ 26 annet ledd). Høyesterett “dømmer i siste instans” (§ 88), herunder hvorvidt en lov er i samsvar med Grunnloven. Å anerkjenne folkerett som en rettskilde i norsk rett, kan forskyve denne maktfordelingen. Man kan derfor tenke seg at Grunnloven, i kraft av sitt system, har et implisitt forbud mot dette. Forbudet kan for eksempel si at folkerettsregler bare kan være norsk rett hvis dette har hjemmel i et vedtak fra et organ som er konstituert av Grunnloven.

Folkerettens stilling i norsk rett er et spørsmål om rettskildelære. Rettskildelæren i norsk rett er hovedsakelig ulovfestet. ${ }^{45}$ Igjen er sedvaneretten (jf. punkt 2 ovenfor) illustrerende: Denne har rang tilsvarende lov eller Grunnlov, og er ikke nevnt eller autorisert av Grunnloven. Altså kan det ikke finnes noe generelt forbud mot å anerkjenne rettskilder som ikke har uttrykkelig hjemmel i Grunnloven eller vedtak fra organer autorisert av Grunnloven.

Det at en anerkjennelse av folkerett som en rettskilde i norsk rett kan forskyve maktfordelingen i Grunnloven, kan likevel være et argument mot slik anerkjennelse. Argumentet vil imidlertid slå ulikt ut i ulike situasjoner. Man kan tenke seg at folkeretten ble gitt en rang lavere enn lover, noe som ikke ville gripe inn i Stortingets lovgivningsmyndighet. Man må også skille mellom ulike typer folkerett, først og fremst traktater og folkerettslig sedvanerett. Visse traktater kan inngås av regjeringen uten Stortingets medvirkning (men riktignok med medvirkning fra minst én annen stat). Folkerettslig sedvanerett skapes på sin side av statspraksis fra (i prinsippet) alle verdens stater (og ikke bare Norge), og norsk statspraksis genereres av alle offentlig organer (og ikke bare regjeringen). Derfor kan det å anerkjenne traktater som en rettskilde i norsk rett flytte makt fra Stortinget til Regjeringen. Samtidig kan man hevde at folkerettslig sedvanerett dannet av en stor gruppe stater har en fjernere forbindelse til norsk rett og norske rettssubjekter enn de rettskildene som i dag er anerkjent i norsk rett, som kan være et argument mot å gi folkerettslig sedvanerett som en rettskilde i norsk rett.

\footnotetext{
${ }^{42}$ Eivind Smith, Konstitusjonelt demokrati: Statsforfatningsretten i prinsipielt og komparativt lys, 2. utg. Bergen 2012 s. 161.

${ }^{43}$ Carl August Fleischer, Folkerett, 8. utg. Oslo 2005 s. 370-371.

44 Johs Andenæs, Statsforfatningen i Norge, 8. utg. Oslo 1998 s. 6

${ }^{45}$ Torstein Eckhoff og Jan Erik Helgesen, Rettskildelære, 5. utg. Oslo 2001 s. 20, Erik Boe, Rettskildelære under debatt, Oslo 2012 s. 21.
} 
Mer generelt kan man merke seg at alle stater som (i større eller mindre grad) har monisme også har parlamenter med lovgivningsmyndighet. Lovgivningsmyndigheten består, og det å kombinere den med monisme er ikke i prinsippet et problem. Det som kan bli et problem er dersom fordelingen av myndighet mellom de norske statsorganene forskyves slik at det konstitusjonelle systemet forstyrres på en uforutsett måte, for eksempel hvis endringen skjer uten tilstrekkelig demokratisk forankring, overveielse og forarbeid. Grunnloven bør behandles som et hele, med et konsekvent og gjennomtenkt system. Å endre ett aspekt av maktfordeling kan ha utilsiktede konsekvenser.

Man kan også ha innsigelser mot den nye myndighetsfordelingen som ville være resultatet av en monismeregel, men da går man inn i en debatt om hva slags konstitusjonelt system som er det optimale. I en slik debatt må ethvert standpunkt begrunnes, også det standpunkt at man foretrekker det nåværende norske systemet.

Den naturlige konklusjonen å trekke fra dette, er at Grunnlovens maktfordeling ikke er grunnlag for noen entydig regel om dualisme, men derimot er et reelt hensyn ${ }^{46}$ som i varierende grad kan være relevant når man vurderer om (og eventuelt hvordan) folkerett bør anerkjennes som en rettskilde i norsk rett. ${ }^{47}$ Dette hensynet bør, sammen med andre relevante hensyn, inngå i en eventuell vurdering av hvorvidt norsk rett bør ha monisme. En slik hensynsvurdering sier imidlertid ikke noe om grunnlaget for den nåværende dualismen, og diskuteres ikke nærmere her.

Konklusjonen er derfor at Grunnlovens system ikke er et grunnlag for den nåværende dualismen i norsk rett. Grunnlovens system er derfor heller ikke et argument for at dualismen må ha konstitusjonell rang.

\subsection{Grunnloven § $\mathbf{2 6}$ forutsetter ikke konstitusjonell norm}

Carl August Fleischer ${ }^{48}$, Johs Andenæs ${ }^{49}$, Gro Nystuen ${ }^{50}$ og Eivind Smith ${ }^{51}$ nevner Grunnloven $\S$ 26 annet ledd som argument for at norsk rett er dualistisk. Det gjør også NOU 1993:18, som sier

\footnotetext{
${ }^{46}$ Reelle hensyn kan defineres som hensynet til en (generell) regel eller et (konkret) resultats godhet, jf. for eksempel Torstein Eckhoff og Jan Erik Helgesen, Rettskildelcre, 5. utg. Oslo 2001 s. 371.

${ }^{47}$ Et annet mulig argument er at Høyesterett kan anses som et organ konstituert av Grunnloven (etter Eivind Smiths terminologi), og at Høyesterett derfor kan anerkjenne folkerett som del av norsk rett. Denne muligheten drøftes ikke nærmere her.

${ }^{48}$ Carl August Fleischer, Folkerett, 8. utg. Oslo 2005 s. 370-371.

49 Johs Andenæs, Statsforfatningen i Norge, 8. utg. Oslo 1997 s. 6,

${ }^{50}$ Gro Nystuen «Rasediskriminerende ytringer og organisasjoner», Institutt for offentlig retts skriftserie, $1991 \mathrm{nr} .4$

s. 1-127, s. 18.

${ }^{51}$ Eivind Smith, Konstitusjonelt demokrati: Statsforfatningsretten i prinsipielt og komparativt lys, 2. utg. Bergen 2012 s. 158.
} 
“Grunnloven § 26 annet ledd [må] dessuten ansees å forutsette et dualistisk system”. Dette er altså en regel med konstitusjonell rang, som brukes for å begrunne at norsk rett er dualistisk.

Grunnloven § 26 annet ledd sier at «[t]raktater om saker som er av særlig stor viktighet, og i alle tilfeller traktater hvis iverksettelse etter Grunnloven nødvendiggjør en ny lov eller stortingsbeslutning, blir først bindende når Stortinget har gitt sitt samtykke dertil». Dette forutsetter iallfall at visse traktater kan nødvendiggjøre ny lov eller stortingsbeslutning for å bli iverksatt. Hvorvidt dette er nødvendig i det enkelte tilfelle, beror på traktatens innhold, først og fremst om den skal ha noen funksjon i partenes interne rett. Dette tilsier at traktater som sådan ikke uten videre blir bindende del av norsk rett, altså norsk rett har en grad av dualisme.

På den annen side, vil traktater som omfattes av "sektormonisme”-regler ikke kreve lov eller stortingsbeslutning for å få direkte virkning i visse deler av norsk rett. Dette illustrerer et mer generelt poeng, nemlig at $\S 26$ annet ledd kun gjelder i den grad en traktat ikke omfattes av en monismeregel: Hvis Norge slutter seg til en traktat som er ment å ha virkning internt i norsk rett, og traktaten omfattes av en monismeregel som sørger for dette, vil ikke traktatens iverksettelse "nødvendiggjør[e] en ny lov eller stortingsbeslutning”. Eksistensen av eventuelle monismeregler i norsk rett er altså forenelig med Grunnloven § 26 annet ledd, og § 26 annet ledd sier ingenting om hvilke slike monismeregler som finnes i norsk rett. Det at § 26 annet ledd finnes, må imidlertid bety at norsk rett ikke kan være fullstendig monistisk. I så fall ville ingen traktater omfattes av bestemmelsen, og den ville være meningsløs.

Grunnloven § 26 annet ledd er derfor ikke et grunnlag for dualismen i norsk rett, den er kun en indikasjon på at norsk rett ikke er fullstendig monistisk. Den eventuelle dualismenormen må finnes i sedvanerett.

Rangen til denne sedvanerettsnormen påvirkes dessuten ikke av at Grunnloven § 26 annet ledd selv har grunnlovs rang. Det er fullt mulig at en grunnlovsregel forutsetter eksistensen av en regel som ikke selv har grunnlovs rang. For eksempel sier Grunnloven § 120 at «[d]et norske flaggs form og farger bestemmes ved lov». Her forutsetter altså Grunnloven eksistensen av en regel som nettopp ikke har grunnlovs rang. Grunnloven § 26 annet ledd gir derfor heller ikke veiledning om hvorvidt dualismen har konstitusjonell rang.

\subsection{Legalitetsprinsippet har ikke betydning}

NOU 1993:18 sier at «legalitetsprinsippet [ble] betraktet som et hinder for en overgang til monisme uten grunnlovsendring». ${ }^{52}$ Legalitetsprinsippet finnes i Grunnloven (§ 113), og brukes altså som argument ikke bare for at norsk rett er dualistisk, men for at den dualismen har konstitusjonell rang.

${ }^{52}$ NOU 1993:18 s. 76. 
Legalitetsprinsippet krever at offentlige inngrep overfor private rettssubjekter har hjemmel i formell lov. ${ }^{53}$ Prinsippets nærmere innhold fastlegges i rettspraksis.

Folkerett regnes normalt ikke som tilstrekkelig hjemmel for vedtak som omfattes av legalitetsprinsippet. Prinsippet kan derfor hindre visse former for monisme i norsk rett. ${ }^{54}$

Legalitetsprinsippet er imidlertid bare relevant for folkerett som pålegger private rettssubjekter forpliktelser overfor det offentlige. Få folkerettsregler gjør dette. De fremste eksemplene er internasjonal strafferett og internasjonal humanitærrett. Såkalt «vertikale» eller «mellomprivate» menneskerettighetsregler vil ikke omfattes, ettersom dette gjelder statens forpliktelse til å hindre privat adferd, snarere enn private forpliktelser overfor staten. Legalitetsprinsippet vil altså i liten grad være til hinder for monisme i norsk rett. ${ }^{55}$ Man kunne for eksempel gitt en generell monismeregel et unntak for folkerettsregler som påla private parter forpliktelser.

Konklusjonen er at legalitetsprinsippet ikke kan brukes som en generell begrunnelse for norsk retts nåværende dualisme. I motsatt fall ville legalitetsprinsippets konstitusjonelle rang innebære at også dualismen var konstitusjonell (og argumentet i NOU 1993:18 ville vært korrekt). Legalitetsprinsippet sier altså ingenting om dualismens rang.

\section{Forrang foran lov krever trinnhøyere norm}

Et annet mulig argument for at dualismen i norsk rett er konstitusjonell, kan være at dersom folkerett skal gå foran lov, må dette være bestemt av en regel med høyere rang enn lovgivning.

Dersom norsk rett hadde hatt det som i denne artikkelen kalles «monisme», måtte folkerettens ranghøyde i norsk rett være presisert nærmere av normen som innførte monisme. I prinsippet kunne folkerettslige regler hatt enhver mulig trinnhøyde, fra under forskrifter til over Grunnloven. Visse ranghøyder for folkeretten ville imidlertid stille krav til trinnhøyde for monismenormen selv. En monismenorm med samme rang som lovgivning, ville ikke kunne si at folkerettslige regler skal gå foran lovgivning. I et slikt tilfelle måtte altså normen som regulerer folkerettens stilling i norsk rett vært konstitusjonell. En lavere ranghøyde for folkeretten, for eksempel at den skulle ha samme rang som lover eller som forskrifter, ville derimot ikke krevd noen konstitusjonell norm.

\footnotetext{
53 Jf. for eksempel Johs Andenæs og Arne Fliflet, Statsforfatningen i Norge, 10. utg. Oslo 2008 s. 226.

${ }^{54}$ Carsten Smith, «Folkerettens stilling ved norske domstoler», Tidsskrift for rettsvitenskap, 1964 s. 356-374, s. 368-369, Carl August Fleischer, Folkerett, 8. utg. Oslo 2005 s. 371-372, Torstein Eckhoff og Jan Erik Helgesen, Rettskildelcre, 5. utg. Oslo 2001 s. 313.

55 Torstein Eckhoff og Jan Erik Helgesen, Rettskildelære, 5. utg. Oslo 2001 s. 313-314.
} 
Man finner avgrensede eksempler på at visse folkerettsregler tilsynelatende har høyere rang enn lov. Dette finnes i regler om sektormonisme (slik som tvisteloven $\S 1-2$, straffeprosessloven $\S 4$, tvangsfullbyrdelsesloven § 1-4, og så videre), og i menneskerettighetsloven § 3 og EØS-loven § 2. Disse reglene er imidlertid alminnelige lover, og de kan derfor fravikes ved senere lov. De aktuelle folkerettsreglene får derfor i realiteten ikke høyere rang enn lov. ${ }^{56}$ Man kan også se hen til sedvaneretten, som diskutert ovenfor i punkt 2. Sedvanerettens eksistens viser at man kan ha regler med samme rang som lov uten at disse er uttrykkelig nevnt i Grunnloven eller nødvendigvis omfattet av en konstitusjonell regel.

For øvrig betyr ingenting av dette at dagens dualismenorm behøver å være konstitusjonell. Det at én potensiell monismenorm (av mange) måtte vært konstitusjonell, har ingen betydning for rangen til den nåværende dualismenormen. Dette argumentet betyr derfor ikke at dualismen behøver å ha konstitusjonell rang.

\section{Rettspraksis er taus om dualismens rang}

\subsection{Innledning}

De foregående punktene i denne artikkelen har konkludert med at dualismenormen i norsk rett ikke følger av Grunnloven, og at den må følge av konstitusjonell eller alminnelig sedvanerett. Det er i praksis domstolene, i siste instans Høyesterett, som fastlegger tolkingen av Grunnloven, og innholdet av konstitusjonell og annen sedvanerett, herunder rettskildenormene. ${ }^{57}$ I praksis vil derfor realiteten være den samme, uansett om man måtte mene at dualismen stammer fra Grunnlov, konstitusjonell sedvanerett eller alminnelig ulovfestet rett: Normen som sier at norsk rett er dualistisk, stammer i praksis fra domstolene.

I dette punktet diskuteres først rettspraksis om folkerettens stilling i norsk rett (punkt 5.2), og deretter hvilken betydning rettspraksis har og kan få for dualismenormens rang (punkt 5.3).

\subsection{Rettspraksis om folkerettens stilling i norsk rett}

I Rt. 1997 s. 580, den såkalte «OFS-» eller «oljestreik»-dommen, la Høyesterett (på s. 592-594) til grunn at norsk rett er dualistisk: «Jeg finner etter dette at selv i tilfelle streikeforbudet skulle ha vært i strid med folkerettslige bestemmelser om vern av retten til streik, ville det følge av norsk rett at den provisoriske anordning om tvungen lønnsnemnd var gyldig.» Dette er den første

\footnotetext{
${ }^{56}$ Carsten Smith, «Fra konvensjon til lov», Mennesker og rettigheter, 1999, s. 267-274, s. 272 kaller dette «semikonstitusjonell» status. Dette beskriver reglenes funksjon i praksis, men ikke om deres formelle rang eller prosedyrene for å endre dem. Eivind Smith, «Semi-konstitusjonell karakter?», Lov og Rett, 2007, s. 385-386, s. 386 er skeptisk til denne begrepsbruken.

${ }^{57}$ Nils Nygaard, Rettsgrunnlag og standpunkt, 2. utg. Oslo 2004 s. 77 og 83-90, Torstein Eckhoff og Jan Erik Helgesen, Rettskildelære, 5. utg. Oslo 2001 s. 20-22, Mads Henry Andenæs, Rettskildelære, 2. utg. Oslo 2009 s. 6 , Erik Boe, Rettskildelære under debatt, Oslo 2012 s. 21, Knut Bergo, Høyesteretts forarbeidsbruk, Oslo 2000 s. 34.
} 
høyesterettsdommen der dette ble sagt klart. ${ }^{58}$ Det ble begrunnet med henvisninger til forarbeider til vedtagelsen av Grunnloven § 93 (daværende § 110c), forarbeider til gjennomføringen av EØS-avtalen, og forarbeider til den provisoriske anordningen som var omtvistet i saken.

At norsk rett er dualistisk, har siden blitt fulgt opp i Rt. 2000 s. $1811^{59}$ og Rt. 2007 s. $234^{60}$, og eventuelt andre dommer ${ }^{61}$. Rt. 2000 s.1811 fant (på s. 1831-1832) at presumsjonsprinsippet i norsk rett ikke gjelder ved motstrid mellom folkerett og nasjonal rett, ettersom norsk rett er dualistisk: «[...] en grense for anvendelsen av presumsjonsprinsippet. Vi er utenfor de tilfeller hvor en bestemmelse «lar seg ... forstå på flere alternative måter» [...]». Rt. 2007 s. 234 begrunnet (i avsnitt 54) et tilsvarende standpunkt med henvisning til Rt. 2000.1811: «Jeg viser til at Norge ved motstrid mellom norsk rett og folkeretten som hovedregel bygger på det dualistiske prinsippet som innebærer at norsk rett går foran folkeretten.»

At dualismen i praksis følger av rettspraksis, kan også kan illustreres ved at domstolene tidligere har kommet til norsk rett har en grad av monisme. ${ }^{62}$ Eksempler fra rettspraksis inkluderer Rt. 1961 s. $1350,{ }^{63}$ Rt. 1966 s. $476,{ }^{64}$ Rt. 1994 s. $610,{ }^{65}$ og eventuelt Rt. 1982 s. $241,{ }^{66}$ Rt. 1983 s.

\footnotetext{
${ }^{58}$ Ken Uggerud, «Internasjonale menneskerettigheter og Høyesteretts dom i Rt. 1997 s. 580 - særlig om bruk av ILO-konvensjoner og Sosialpakten», Lov og Rett, 1997 s. 581-618, s. 582, som også påpeker at det er snakk om et obiter dictum.

59 Jf. Erik Boe, Innføring i juss: Juridisk tenkning og rettskildelære, 3. utg. Oslo 2010 s. 110, Morten Ruud og Geir Ulfstein, Innføring i folkerett, 4. utg. Oslo 2011 s. 58, Mads Henry Andenæs, Rettskildelcre, 2. utg. Oslo 2009 s. 58, Hans Petter Graver, «Internasjonale konvensjoner som rettskilde», Lov og Rett, 2003 s. 468-489, s 474-475, Jens Edvin Andreassen Skoghøy, «Norske domstolers lovkontroll i forhold til inkorporerte menneskerettskonvensjoner», Lov og Rett, 2002 s. 337-354, s. 338, Jens Edvin Andreassen Skoghøy, «Høyesteretts bruk av menneskerettskonvensjonene som rettskilde før og etter menneskerettsloven», i Peter Lødrup mfl. (red.), Rettsteori og rettsliv: festskrift til Carsten Smith, Oslo 2002 s. 733-761, s. 733, Erik Boe, Rettskildelcre under debatt, Oslo 2012 s. 388.

60 Jf. Eivind Smith, Konstitusjonelt demokrati: Statsforfatningsretten i prinsipielt og komparativt lys, 2. utg. Bergen 2012 s. 159, Erik Boe, Innføring i juss: Juridisk tenkning og rettskildelcre, 3. utg. Oslo 2010 s. 110, Mads Henry Andenæs, Rettskildelcre, 2. utg. Oslo 2009 s. 58, Finn Arnesen og Are Stenvik, Internasjonalisering og juridisk metode: Scerlig om EØS-rettens betydning i norsk rett, Oslo 2009 s. 49.

${ }^{61}$ Rt. 2010 s. 1445 nevnes av Eivind Smith, Konstitusjonelt demokrati: Statsforfatningsretten i prinsipielt og komparativt lys, 2. utg. Bergen 2012 s. 159, Rt. 2001 s. 1006 av Jens Edvin Andreassen Skoghøy, «Norske domstolers lovkontroll i forhold til inkorporerte menneskerettskonvensjoner», Lov og Rett, 2002 s. 337-354, s. 338 og Jens Edvin Andreassen Skoghøy, «Høyesteretts bruk av menneskerettskonvensjonene som rettskilde før og etter menneskerettsloven», i Peter Lødrup mfl. (red.), Rettsteori og rettsliv: festskrift til Carsten Smith, Oslo 2002 s. 733 761, s 733.

62 Jf. Knut Bergo, Høyesteretts forarbeidsbruk, Oslo 2000 s. 13, om at Høyesterett «gang på gang har endret de juridiske metodene, slik at den teoretiske rettskildelæren etter en stund blir misvisende», Torstein Eckhoff og Jan Erik Helgesen, Rettskildelcre, 5. utg. Oslo 2001 s. 324 antar at «Høyesterett ikke vil føle seg bundet av uttalelsen [om dualisme i OFS-dommen], om retten i en senere sak [...] skulle ønske å endre standpunkt».

${ }^{63}$ Eivind Smith, Konstitusjonelt demokrati: Statsforfatningsretten i prinsipielt og komparativt lys, 2. utg. Bergen 2012 s. 164-165.

${ }^{64}$ Eivind Smith, Konstitusjonelt demokrati: Statsforfatningsretten i prinsipielt og komparativt lys, 2. utg. Bergen 2012 s. 164-165, Carl August Fleischer, Rettskilder og juridisk metode, Oslo 1998 s. 517.

${ }^{65}$ Ken Uggerud, «Bruk av tvungen lønnsnemnd i rettslig belysning - randmerknader til en byrettsdom», Kritisk Juss, 1996 nr. 3 s. $164-169$, s. 166.
} 
$1004^{67}$ og to dommere i Rt. 1946 s. $196^{68}$ («Klingedommen»). Eivind Smith kritiserer flere av dommene for å være «uten uttrykkelig støtte i grunnlov eller lov». ${ }^{69}$ At Høyesterett utvikler rettskildelæren uten uttrykkelig hjemmel i lov burde imidlertid ikke være overraskende, ettersom de fleste rettskildenormer i norsk rett nettopp er ulovfestede. Eldre forarbeider er også mindre

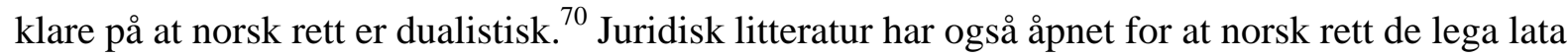
iallfall ikke var rent dualistisk. ${ }^{71}$ Et tidsmessig skille, både for litteratur og forarbeider, går omtrent ved avsigelsen av OFS-dommen (Rt. 1997 s. 580). Altså har folkerettens stilling i norsk rett har fluktuert over tid, i takt med rettspraksis, til tross for at mye av Grunnloven, lovgivningen og øvrig praksis har forblitt den samme.

\subsection{Betydning for dualismens rang}

Man kan altså si at rettspraksis er dualismens "egentlige” grunnlag. Det er i praksis domstolene som har avgjort at norsk rett er dualistisk, og de har i den forbindelse hatt mulighet til å ta stilling til dualismenormens rang. De har imidlertid sagt noe om hvorvidt deres konklusjoner om dualisme er basert på en konstitusjonell norm. Rettspraksisen som er nevnt ovenfor gir derfor ingen veiledning om dualismenormens rang.

Som nevnt i punkt 1 og 2.3 ovenfor, kan spørsmålet om dualismenormens rang komme på spissen dersom Stortinget forsøker å vedta lovgivning som går lengre enn dagens regler om sektormonisme og inkorporasjon. I et slikt tilfelle er det domstolene som eventuelt må stilling til om slik lovgivning går utover det dualismenormen tillater, ved å trekke den grensen som ble

\footnotetext{
${ }^{66}$ Se kommentar i Jan Fridthjof Bernt, «Den europeiske menneskerettskonvensjonen og norsk forvaltningsrett», Jussens Venner, 1995 s. 159-188, s. 161.

${ }^{67}$ Carl August Fleischer, Rettskilder og juridisk metode, Oslo 1998 s. 517.

68 Thomas Frøberg, «Kan den strafferettslige klassifikasjonen av en handling gis tilbakevirkende kraft?», Lov og Rett, 2008 s. 342-360, s. 352.

${ }^{69}$ Eivind Smith, Konstitusjonelt demokrati: Statsforfatningsretten i prinsipielt og komparativt lys, 2. utg. Bergen 2012 s. 164.

${ }^{70}$ NOU 1984:18 diskuterer uenighet i juridisk litteratur, Ot.prp. nr. 33 (1986-7) s. 106 diskuterer tendenser i rettspraksis.

${ }^{71}$ Oversikter finnes i NOU 1993:18 s. 70-74, Jørgen Aall, «Menneskerettighetskonvensjoner som rettskildefaktor i intern norsk rett», Tidsskrift for rettsvitenskap, 1989 s. 613-639, s. 618, Ken Uggerud, «Internasjonale menneskerettigheter og Høyesteretts dom i Rt. 1997 s. 580 - særlig om bruk av ILO-konvensjoner og Sosialpakten», Lov og Rett, 1997 s. 581-618, s. 582. Standpunkter fremmes i Terje Einarsen, «Asylrettens grunnlovsvern - etter Kjuus-saken», Kritisk juss, 1998 s. 123-152, s. 146, Gunnar Nerdrum, «Menneskerettighetene ved en skilleveg?», Lov og Rett, 1997 s. 102-111, s 103, Ken Uggerud, «Bruk av tvungen lønnsnemnd i rettslig belysning randmerknader til en byrettsdom», Kritisk Juss, 1996 nr. 3 s. 164-169, s. 166, Jan Fridthjof Bernt, «Den europeiske menneskerettskonvensjonen og norsk forvaltningsrett», Jussens Venner, 1995 s. 159-188, s. 161, Arvid Aage Skaar, «I 1949-lovens grenseland: Diskrimineringsklausulen og norsk rett», Skatterett, 1985 s. 221-242, s. 225 og $235-$ 242, Peter Ørebech, «Om norsk lovgivnings anvendelse på Svalbard», Lov og Rett, 1985 s. 164-177, s. 167, Carsten Smith, «Om Internasjonale menneskerettigheter og nasjonale domstoler», Jussens Venner, 1980 s. 302-314, s. 303 og 314, Carsten Smith «Folkerettens stilling ved norske domstoler», Tidsskrift for rettsvitenskap, 1964 s. 356-374, s. 369-370, Carl August Fleischer, Rettskilder og juridisk metode, Oslo 1998 s. 517, Torstein Eckhoff, Rettskildelære, 3. utg. Oslo 1993, s. 260-266.
} 
skissert i punkt 2.3. Da vil det også bli nødvendig for dem å ta stilling til dualismenormens rang, ettersom Stortingets lovvedtak kun vil være ugyldig dersom dualismenormen er konstitusjonell. Behovet for å trekke denne grensen overhodet forutsetter for øvrig at domstolene opprettholder den dualismenormen som ble knesatt i OFS-dommen. Hvis domstolene er ukomfortable med å trekke en slik grense, står i praksis fritt til å fravike sitt eget prejudikat.

Domstolene kan altså i praksis avgjøre ikke bare om det finnes en dualismenorm i norsk rett og hvor langt denne går, men også hvilken rang den har.

\section{Konklusjon}

Denne artikkelen har undersøkt hvorvidt normen som bestemmer at norsk rett er dualistisk har konstitusjonell rang. Dette spørsmålet ser ikke ut til å ha blitt grundig undersøkt tidligere, selv om det er en viktig bakgrunn for Stortingets adgang til å vedta lovgivning om folkerettens stilling i norsk rett. I likhet med rettskildelæren for øvrig, følger ikke dualismenormen av Grunnloven selv. Den ser derimot ut til å følge av konstitusjonell sedvanerett. Argumenter basert Grunnloven §§ 26 og 113 og Grunnlovens system er beviser imidlertid ikke dette. Det gjør ikke hele et argument om at folkerett som skal ha forrang foran lov må hvile på en norm med høyere rang enn lov. Spørsmålet er altså mer åpent enn man kan få inntrykk av ved å lese eksisterende forarbeider og litteratur.

Siden dualismenormen ser ut til å være konstitusjonell, må den angi hva slags innføring av folkerett i norsk rett som kan vedtas i lovs form av Stortinget. Den mest plausible konklusjonen er at Stortinget ikke kan bestemme at et ubestemt sett med folkerettsregler skal gjelde generelt i norsk rett, men at det ellers står fritt. Ettersom det er domstolene som i praksis har fastsatt dagens dualismenorm, er det også disse som eventuelt må ta endelig stilling til hvor grensen går for Stortingets lovgivningsmyndighet på dette punktet.

Det nåværende dualistiske system fungerer fint i praksis, til tross for disse uklarhetene. Selv om spørsmålet ikke behøver å komme på spissen i overskuelig fremtid, er det fundamentalt sett snakk om en konstitusjonell debatt, og potensiell maktkamp, mellom to av våre øverste statsmakter. 


\section{Litteraturliste}

Lover

Constitution of the United States of America (17. September 1787) (USAs grunnlov)

Artikkel VI

Lov 17. mai 1814 Kongeriket Norges Grunnlov (Grunnloven)

$\S 26 \S 113 \S 49 \S 75 \S 88 \S 120 \S 93$

Almindelig borgerlig Straffelov 22. mai 1902 (strl.)

$\S 1$

Lov 22. mai 1981 nr. 25 om rettergangsmåten i straffesaker (strpl.)

$\S 4$

Lov 26. juni $1992 \mathrm{nr} .86$ om tvangsfullbyrdelse (tvangsl.)

$\S 1-4$

Lov 27. november $1992 \mathrm{nr} .109$ om gjennomføring i norsk rett av hoveddelen i avtale om Det europeiske økonomiske samarbeidsområde (EØS-loven)

$\S 1 \S 2$

Lov 4. august $1995 \mathrm{nr} .53$ om politiet (politil.)

$\S 3$

Lov 21. mai $1999 \mathrm{nr} .30$ om styrking av menneskerettighetenes stilling i norsk rett (menneskerettsloven)

$\S 2 \S 3$

Lov 5. mars 2004 nr. 11 om gjennomføring og kontroll av EØS-avtalens konkurranseregler mv. (EØS-konkurranseloven)

$\S 4$

Lov 20. mai 2005 nr. 28 om straff (strl. 2005)

$\S 2$

Lov 17. juni $2005 \mathrm{nr} .90$ om mekling og rettergang i sivile tvister (tvisteloven)

$\S 1-2$

\section{Traktater}

Statute of the International Court of Justice (vedtatt 26. juni 1945, i kraft 24. oktober 1945) (ICJstatuttene)

\section{Artikkel 38}

Vienna Convention on the Law of Treaties (vedtatt 23. mai 1969, i kraft 27. januar 1980) (Wienkonvensjonen om traktatretten)

Artikkel 31-32

Forarbeider og andre offentlige dokumenter

Dok. 16 (2011-2012), Rapport til Stortingets presidentskap fra Menneskerettighetsutvalget om menneskerettigheter i Grunnloven 
Innst. O. nr. 51 (1998-99), Innstilling frå justiskomiteen om lov om styrking av menneskerettane si stilling i norsk rett (menneskerettsloven)

Innst. 69 S (2013-2014), Innstilling frå justiskomiteen om samtykkje til å trekkje reservasjonen mot FN-konvensjonen 11. april 1980 om kontraktar for internasjonale lausøyrekjøp (CISG) del II om avtaleinngåing

NOU 1972:16, Gjennomføring av lovkonvensjoner i norsk rett - fra et utvalg til å utrede spørsmålene ved transformasjon av internasjonale lovkonvensjoner til norsk rett

(Transformasjonskomitéen)

NOU 1984:18, Om samenes rettsstilling

NOU 1993:18, Lovgivning om menneskerettigheter

NOU 2002:12, Rettslig vern mot etnisk diskriminering

Ot.prp. nr. 33 (1986-87), Om lov om Sametinget og andre samisk rettsforhold (sameloven)

Ot.prp. nr. 79 (1991-92), Om lov om gjennomføring i norsk rett av hoveddelen i Avtale om Det europeiske økonomiske samarbeidsområde (EØS), mv.

Ot.prp. nr. 3 (1998-99), Om lov om styrking av menneskerettighetenes stilling i norsk rett (menneskerettsloven)

Ot.prp. nr. 45 (2002-2003), Om lov om endring i menneskerettsloven mv. (innarbeiding av barnekonvensjonen i norsk lov)

Ot.prp. nr. 33 (2004-2005), Om lov om forbud mot diskriminering på grunn av etnisitet, religion mv. (diskrimineringsloven)

Ot.prp. nr. 35 (2004-5), Om lov om endringer i likestillingsloven mv. (Gjennomføring av Europaparlaments- og rådsdirektiv 2002/73/EF og innarbeiding av FN-konvensjonen om avskaffelse av alle former for diskriminering av kvinner med tilleggsprotokoll i norsk lov) Ot.prp. nr. 93 (2008-2009), Om lov om endringar i menneskerettsloven mv. (inkorporering av kvinnediskrimineringskonvensjonen)

St.meld. nr. 17 (2004-2005) Makt og demokrati

Utenriksdepartementet, Folkerettslige avtaler: Om forhandling og inngåelse av folkerettslige avtaler, Oslo 2013

\section{Dommer}

Rt. 1946 s. 196

Rt. 1961 s. 1350

Rt. 1966 s. 476

Rt. 1982 s. 241

Rt. 1983 s. 1004

Rt. 1994 s. 610

Rt. 1997 s. 580

Rt. 2000 s.1811

Rt. 2007 s. 234

Rt. 2010 s. 1445 


\section{Litteratur}

Aall, Jørgen, «Menneskerettighetskonvensjoner som rettskildefaktor i intern norsk rett», Tidsskrift for rettsvitenskap, 1989 s. 613-639

Andenæs, Johs, Statsforfatningen i Norge, 8. utg. Oslo 1998

Andenæs, Johs og Arne Fliflet, Statsforfatningen i Norge, 10. utg. Oslo 2006

Andenæs, Mads Henry, Rettskildelcere, 2. utg. Oslo 2009

Arnesen, Finn og Are Stenvik, Internasjonalisering og juridisk metode: Scerlig om EØS-rettens betydning i norsk rett, Oslo 2009

Aune, Helga, «Likebehandlingsprinsippet og arbeidstakere i deltidsstilling», Institutt for offentlig retts skriftserie, $1997 \mathrm{nr} .2$ s. 1-116

Backer, Inge Lorange, «Lovgivere og domstoler ved begynnelsen av det 21. århundre», Jussens Venner, 2006 s. 248-266

Bergo, Knut, Høyesteretts forarbeidsbruk, Oslo 2000 s. 34

Bernt, Jan Fridthjof, «Den europeiske menneskerettskonvensjonen og norsk forvaltningsrett», Jussens Venner, 1995 s. 159-188

Boe, Erik, Innføring i juss: Juridisk tenkning og rettskildelæere, 3. utg. Oslo 2010

Boe, Erik, Rettskildelære under debatt, Oslo 2012

Broch, Lars Oftedal, "Den Europeiske menneskerettighetskonvensjonens inkorporering i norsk rett”, Mennesker og rettigheter, 2000, s. 176-181

Bull, Henrik, «The EEA Agreement and Norwegian Law», European Business Law Review, 1994 nr 12 s. 291-296

Denza, Eileen, «The Relationship Between International and National Law», i Malcolm Evans (red.), International Law, 4. utg. Oxford 2014

Eckhoff, Torstein, Rettskildelcre, 3. utg. Oslo 1993

Eckhoff, Torstein og Jan Erik Helgesen, Rettskildelære, 5. utg. Oslo 2001

Einarsen, Terje, «Asylrettens grunnlovsvern - etter Kjuus-saken», Kritisk juss, 1998 s. 123-152

Emberland, Marius, «To måter å bringe rettigheter hjem på», Retfcerd, 2002 s. 3-22

Fleischer, Carl August, Rettskilder og juridisk metode, Oslo 1998

Fleischer, Carl August, Folkerett, 8. utg. 2005

Fliflet, Arne, Grunnloven: Kommentarutgave, Oslo 2005

Fredriksen, Halvard Haukeland, «Bokanmeldelse: Finn Arnesen og Are Stenvik:

Internasjonalisering og juridisk metode. Universitetsforlaget, Oslo 2009. 160 sider», Lov og Rett, 2010 s. 98-101

Frøberg, Thomas, «Kan den strafferettslige klassifikasjonen av en handling gis tilbakevirkende kraft?», Lov og Rett, 2008 s. 342-360

Graver, Hans Petter, «Internasjonale konvensjoner som rettskilde», Lov og Rett, 2003 s. 468-489

Helgesen, Jan Erik, «Om den såkalte "konstitusjonelle sedvanerett”», Jussens Venner, 1977 s. 193-240

Helgesen, Jan, Teorier om "Folkerettens stilling i norsk rett”, Oslo 1982 
Helset, Per og Bjørn Stordrange, Norsk statsforfatningsrett, Oslo 1998

Krüger, Kai, «Svensk privatrett sett fra norsk side - samt noen refleksjoner over nordisk rettsidentitet i privatrettsforskningen med blikk mot fortid og fremtid», i Stig Strömholm (red.), Svensk rättsvetenskap 1947-1997, Stockholm 1997 s. 23-59

Krüger, Kai, «Kampen om begrepene - En feltrapport fra EØS-fronten: Stat, politikk og folkestyre», i David Doublet mfl. (red.), Festskrift til Per Stavang på 70-årsdagen 19. Februar, Bergen 1998 s. 429-454

Krüger, Kai, «Finanger-dommen og den nye rettskildefaktor: frykten», Jussens Venner, 2001 s. 89-104

Johansen, Jon Petter Rui, «Ikke inkorporert folkerett i konflikt med norsk rett», i Per Christiansen (red.), Jubileumsskrift til Universitetet i Tromsø: Fra Driftssentralen til Teorifagbygget, Tromsø 2004 s. 117-131

Johansen, Stian Øby, «Den internasjonale rettens påvirkning på norsk rett», Pacta, nr 232014 s. 34-37

Nerdrum, Gunnar, «Menneskerettighetene ved en skilleveg?», Lov og Rett, 1997 s. 102-111 Nygaard, Nils, Rettsgrunlag og standpunkt, 2. utg. Bergen 2004

Nystuen, Gro, «Rasediskriminerende ytringer og organisasjoner», Institutt for offentlig retts skriftserie, $1991 \mathrm{nr} .4$ s. 1-127

Ruud, Morten og Geir Ulfstein, Innføring i folkerett, 4. utg. Oslo 2011

Sejersted, Fredrik, Kontroll og konstitusjon, Oslo 2002

Sejersted, Fredrik mfl., EØS-rett, 3. utg. Oslo 2011

Skaar, Arvid Aage, «I 1949-lovens grenseland: Diskrimineringsklausulen og norsk rett», Skatterett, 1985 s. 221-242

Skoghøy, Jens Edvin Andreassen, «Forholdet mellom internasjonale menneskerettigheter og norsk rett», Kritisk Juss, 1998 s. 111-119

Skoghøy, Jens Edvin Andreassen, «Høyesteretts bruk av menneskerettskonvensjonene som rettskilde før og etter menneskerettsloven», i Peter Lødrup mfl. (red.), Rettsteori og rettsliv: festskrift til Carsten Smith, Oslo 2002 s. 733-761

Skoghøy, Jens Edvin Andreassen, «Norske domstolers lovkontroll i forhold til inkorporerte menneskerettskonvensjoner», Lov og Rett, 2002 s. 337-354

Smith, Carsten, «Folkerettens stilling ved norske domstoler», Tidsskrift for rettsvitenskap, 1964 s. 356-374

Smith, Carsten, «International Law In Norwegian Courts», Scandinavian Studies in Law, 1968 s. 151-201

Smith, Carsten, «Om Internasjonale menneskerettigheter og nasjonale domstoler», Jussens Venner, 1980 s. 302-314

Smith, Carsten, «Fra konvensjon til lov», Mennesker og rettigheter, 1999, s. 267-274

Smith, Eivind, «Semi-konstitusjonell karakter?», Lov og Rett, 2007, s. 385-386

Smith, Eivind, «Vil de som er imot, rekke opp hånden? - Om menneskerettigheter, (annen) rett og demokrati», Nytt Norsk Tidsskrift, 2011 nr. 1 s. 49-59 
Smith, Eivind, Konstitusjonelt demokrati: Statsforfatningsretten i prinsipielt og komparativt lys, 2. utg. Bergen 2012

Thirlway, Hugh, «The Sources of International Law», i Malcolm Evans (red.), International Law, 4. utg. 2014 s. 91-117

Uggerud, Ken, «Bruk av tvungen lønnsnemnd i rettslig belysning - randmerknader til en byrettsdom», Kritisk Juss, 1996 nr. 3 s. 164-169

Uggerud, Ken, «Internasjonale menneskerettigheter og Høyesteretts dom i Rt. 1997 s. 580 særlig om bruk av ILO-konvensjoner og Sosialpakten», Lov og Rett, 1997 s. 581-618

Ørebech, Peter, «Om norsk lovgivnings anvendelse på Svalbard», Lov og Rett, 1985 s. 164-177

Ulfstein, Geir, ”Internasjonal miljøretts stilling i norsk rett”, Lov og Rett, 1999 s. 402-417 